\title{
Az OECD OKTATÁSI INDIKÁTORAI
}

\author{
VARGA JÚLIA \\ Közgazdaság- és Regionális Tudományi Kutatóközpont Közgazdaságtudományi Intézete \\ Beérkezett: 2021. szeptember 6., elfogadva: 2021. október 24.
}

A tanulmány az OECD oktatási indikátorrendszerének történetét foglalja össze. Az indikátorrendszer példáján keresztül azt mutatja be, hogy abban, hogy az OECD az oktatáspolitikában kulcsszereplővé tudott válni három momentum meghatározó jelentőségű volt: az első, hogy az OECD folyamatosan integrálni tudta az oktatással kapcsolatos munkájába az újabb és újabb tudományos kutatási eredményeket, elsősorban az oktatásgazdaságtani kutatások eredményeit. A második, az oktatási adatok szisztematikus, kutatási eredményeken alapuló gyűjtése, és az adatgyűjtések és azok nemzetközi összehasonlíthatóságának folyamatos fejlesztése volt, melynek nyomán az OECD egy nagy nemzetközi, összehasonlítható oktatásstatisztikai adatbázist tudott létrehozni. A harmadik, hogy az OECD az oktatási adatait folyamatosan, ingyenesen hozzáférhetővé tette, azokat bárki ingyen letöltheti, és felhasználhatja saját kutatásaihoz.

Kulcsszavakः oktatási indikátorrendszer, nemzetközi összehasonlíthatóság, nemzetközi oktatásstatisztikai adatbázis

The study gives a summary of the history of the OECD education indicator system. Through the example of the indicator system, it presents that three moments were crucial in the OECD becoming a key player in education policy. First, that the OECD was able to continuously integrate the new scientific results, especially findings of educational economics research, into its education work. The second was the systematic collection of education data based on research results and the continuous improvement of the international comparability of data which enabled the OECD to create a large international, comparable database of education statistics. The third is that the OECD has made its education data available continuously, free of charge so that anyone can download it for free and use it for their own research.

Keywords: education indicator system, international comparability, international education statistics database

Levelező szerző: Varga Júlia, Közgazdaság- és Regionális Tudományi Kutatóközpont Közgazdaságtudományi Intézete, 1097 Budapest, Tóth Kálmán u.4., E-mail: varga.julia@krtk.hu 


\section{Bevezetés}

$\mathrm{N}$ ehezen lehetne olyan, az oktatással, oktatáspolitikával foglalkozó szakembert, vagy e kérdések iránt komolyabban érdeklődőt találni, aki ne hallott volna az OECD oktatási indikátorairól, oktatási indikátorrendszeréről vagy az ezekhez kapcsolódó kiadványokról, elsősorban az évente megjelenő "Education at a Glance” kötetekről. Ha együtt keresünk rá az interneten az „OECD”, „education” és „indicator” szavakra, a Google keresője 17800000 olyan találatot mutat, melyben mindhárom szó szerepel. Az OECD az elmúlt évtizedekben meghatározó szerepre tett szert az összehasonlítható oktatási statisztikai adatszolgáltatásban, az oktatási rendszerek nemzetközi összehasonlító értékelésében, a különböző oktatáspolitikai eszközök hatékonyságának vizsgálatában. Évről évre egyre több ország kapcsolódik be az adatszolgáltatásba, jelenik meg az indikátorkötetekben az OECD-tagországokon kívül is. Az OECD oktatáspolitikai hatása annyira meghatározó, hogy az utolsó években számos cikk próbált magyarázatot adni arra, hogy miért és hogyan tudott az OECD ilyen meghatározó pozícióba kerülni. A tanulmányok különböző előfeltételezések mentén vizsgálták ezt a kérdést, sok munka politikai vagy intézményi okokat vélt e hatás mögött megtalálni (pl. Grek 2009; Bürgi 2017).

Ebben a cikkben azt mutatom be az OECD oktatási indikátorrendszerének kidolgozása és az indikátorrendszer elmúlt évtizedekben megvalósult fejlesztése példáján, hogy abban, hogy az OECD oktatáspolitikai szerepe ilyen meghatározóvá tudott válni, három momentumnak alapvető szerepe volt. Az első, hogy az OECD folyamatosan integrálni tudta az oktatással kapcsolatos munkájába az újabb és újabb tudományos eredményeket, elsősorban az oktatásgazdaságtani kutatások eredményeit. A második az oktatási adatok szisztematikus, folyamatos, hozzáértő, kutatási eredményeken alapuló gyüjtése és az adatgyüjtések összehasonlíthatóságának folyamatos fejlesztése volt, melynek nyomán az OECD egy rendkívül részletes, nemzetközi, összehasonlítható oktatásstatisztikai adatbázist tudott létrehozni. A harmadik, hogy az OECD az oktatási adatait - beleértve saját adatfelvételeinek mikroszintű adatait is - folyamatosan, ingyenesen hozzáférhetővé tette, azokat bárki térítés nélkül letöltheti és felhasználhatja saját kutatásaihoz. Ez további ösztönzést ad az oktatás nemzetközi összehasonlító kutatásainak, melynek eredményeit azután az OECD ismét felhasználja az oktatással kapcsolatos munkájában.

\section{Az OECD és az oktatásgazdaságtani kutatások}

Az 1950-es évek végén, hatvanas évek elején a közgazdászok és számos nemzetközi szervezet a gazdasági növekedés feltételeinek megteremtését tekintették a legfontosabb feladatuknak. Az 1961-ben létrejött OECD gazdasági szervezetként jött létre, abból a deklarált célból, hogy a lehető legnagyobb, fenntartható gazdasági növekedést, foglalkoztatást, növekvő életszínvonalat segítsen elérni a tagországokban, miközben azok megőrzik pénzügyi stabilitásukat és hozzájárulnak a világgazdaság növekedéséhez (OECD 1960). Ezért nem meglepő, hogy az, hogy az OECD érdeklődése mekkora mértékben fordult az oktatás felé, az annak a függvényében változott, hogy a közgazdaságtan mi- 
lyen gazdasági szerepet tulajdonított az oktatásnak. Az OECD megalakulása és a közgazdaságtanban az oktatás gazdasági szerepének átértékelése egybeesett időben.

Az 1950-es évek végétől, 1960-as évektől kezdődően alapvetően megváltozott a kutató közgazdászok egy részének körében az oktatás szerepének megítélése. Ebben az időben a gazdasági növekedés forrásait vizsgáló kutatásokban egyre nyilvánvalóbbá vált, hogy ha a növekedést csak a hagyományosan figyelembe vett termelési tényezőkkel próbálják magyarázni, akkor a növekedés nagy része megmagyarázatlan marad (pl. Solow 1967), ezért egyre inkább a növekedést magyarázó tényezőként tekintettek az iskolázottság növekedésére (lásd pl. Denison 1962, 1967, 1974, 1985; Schultz, 1961a), és ez vezetett az emberi tőke elmélet formális kidolgozásához (Becker 1962; Schultz 1961b; Mincer 1973). Az emberi tőke elmélet kidolgozása alapvető változást hozott a közgazdászok, gazdasági szakemberek és szervezetek oktatás iránti érdeklődésében. Addig, ameddig a közgazdászok az oktatást egyszerüen fogyasztási cikknek tekintették, a legtöbb közgazdász szinte egyáltalán nem foglalkozott az oktatással, vagy legfeljebb annyiban, hogy hogyan lehetne a költségvetés oktatási kiadásait a lehető legalacsonyabb szinten tartani. Az volt az általános felfogás, hogy az oktatás iránti keresletet - más fogyasztási cikkekéhez hasonlóan - a személyes preferenciák, a családi jövedelem, és az oktatás költségei határozzák meg, az államnak vagy a gazdasági szakembereknek nem sok dolguk van az oktatással, az a pedagógusok, pszichológusok és hasonló szakemberek problémája. Az emberi tőke elmélet kidolgozása azonban fokozatosan forradalmi változásokat idézett elő: az oktatás a közgazdászok szemében fogyasztási cikkből beruházássá alakult át, és mint ilyen, valódi érdeklődést váltott ki a szakértők, döntéshozók, politikusok, szociológusok, közgazdászok, statisztikusok körében.

Az oktatásgazdaságtan eredményei nagyon korán eljutottak az OECD-hez is, sőt az OECD maga is hozzájárult az oktatásgazdaságtan mint önálló diszciplína megerősödéséhez. 1961-ben, rögtön az OECD megalakulása után az OECD konferenciát szervezett a Brookings Intézettel együtt Washingtonban a gazdasági növekedés és az oktatásba történő beruházások kapcsolatáról. A magas rangú tisztviselők mellett számos olyan közgazdász is részt vett az eseményen, akit ma már az oktatásgazdaságtan úttörőinek tekintünk, mint Seymour Harris (Egyesült Államok), Selma J. Mushkin (Egyesült Államok), John Vaizey (Egyesült Királyság), Friedrich Edding (Németország), vagy Jan Tinbergen (Hollandia). A konferencia nemcsak a tudományos vitára kínált lehetőséget, hanem lehetőséget adott a tudományos világ és az OECD tisztségviselői, alkalmazottai közötti kapcsolat erősítésére is (Teixera 2019). A konferenciát követően az OECD létrehozott egy Oktatásgazdaságtani Kutatócsoportot, mely 1965-ig müködött és melyben ugyancsak számos közgazdász vett részt az oktatásgazdaságtan első képviselői közül (pl. F. Edding, S. Harris, J. Vaizey és H. Parnes).

A csoport nagy része keynesiánus nézeteket képviselt, támogatták az oktatástervezést, azt képviselték, hogy az oktatást a gazdaság igényeihez kell igazítani (OECD 1962). Az oktatás és gazdasági növekedés kapcsolatát meglehetősen szüken értelmezték, azt feltételezték, hogy a növekedést elsősorban a müszaki és tudományos munkakörökben dolgozók serkentik. Ezért, az OECD oktatási munkája ekkor elsősorban arra irányult, hogy a kevésbé fejlett tagországok felzárkóztatását célzó középtávú oktatási terveket dolgozzon ki. Az első ilyen középtávú terv az úgynevezett Mediterrán Regionális Projekt volt, ami az első jelentős kísérlet volt nemzetközi oktatási tervek készítésére. A terv az oktatást a kívánt gazdasági növekedés igényeihez próbálta igazítani. 
A projektbe azokat az országokat vonták be, melyek a többi OECD-tagországhoz képest kevésé fejlettek voltak, és népességük kevésbé volt iskolázott, így Spanyolországot, Olaszországot, Portugáliát, Törökországot, Jugoszláviát és Görögországot. Az oktatástervezési kísérleteket aztán az OECD kiterjesztette egy másik projekt keretében a latin-amerikai országokra is.

Bár az oktatástervezési kísérletek nem voltak sikeresek, és az 1960-as évek végén felhagyott velük az OECD, ezek a munkák hatással voltak az OECD későbbi oktatási munkáira is. Egyrészt, az oktatási tervekhez számos tanulmányt készíttetett az OECD, és ezzel hozzájárultak a matematikai közgazdaságtan fejlődéséhez, az ökonometriai módszereket alkalmazó oktatásgazdaságtan kialakulásához, ami alapvetően megváltoztatta az oktatási rendszerek összehasonlító elemzési eszközeit. Jan Tinbergen holland kutató közgazdász, akit az ökonometriai közgazdaságtan egyik megalapítójának tartanak (és aki Ragnar Frisch norvég közgazdásszal együtt az első közgazdasági Nobel-díjazott volt 1969-ben) szakértőként dolgozott az OECD-nek, és másokkal együtt oktatástervezési modellt dolgozott ki az OECD számára (TinbergenBos 1964). Másrészt az oktatási tervekhez összehasonlítható, részletes adatokra volt szükség, ezért az OECD elkezdett szisztematikusan oktatási adatgyüjtésekkel és az adatok összehasonlíthatóságának biztosításával foglalkozni.

Ezek az adatgyüjtések és a hozzájuk kapcsolódó módszertani kiadványok az előzményei voltak a későbbi, az oktatási indikátorokhoz szükséges adatgyüjtéseknek. Az adatgyüjtés elősegítésére, ösztönzésére és egységesítésének elősegítésére 1967-ben az OECD kiadott egy kézikönyvet az Oktatástervezéshez szükséges statisztikák és módszerek (Statistical Needs for Educational Planning, OECD 1967) címmel. Ez a kiadvány foglalkozott elöször azzal, hogy módszertani útmutatót adjon a tagországoknak, hogy az oktatással kapcsolatban milyen statisztikai adatokat érdemes gyưjteniük, és hogyan lehet biztosítani az adatok nemzetközi összehasonlíthatóságát.

$\mathrm{Az}$ 1960-as évek végétől, 1970-es évek elejétől a gazdasági növekedés lassult az OECD-országokban és ez elsöpörte a korábbi lelkesedést az oktatás növekedésben játszott szerepével kapcsolatban. Ennek nyomán jelentek meg az emberi tőke elmélettel szembeni alternatív elméletek, a különböző szürési modellek, melyek alapvetően kérdőjelezték meg az oktatás termelékenységet növelő hatását (Berg 1970; Spence 1973; Arrow 1973). Ekkor kezdtek munkába állni a háború után született népesebb, „baby-boomer” korosztályok, ami az ifjúsági munkanélküliség növekedését eredményezte, ezért az OECD érdeklődése is elsősorban az oktatásból a munkába történő átmenet kérdése felé fordult. Ebben az időszakban az oktatástervezés szerepével kapcsolatos kétségek általános szkepticizmust eredményeztek az oktatás gazdasági szerepének egészével szemben (Papadopoulos 1994).

Ennek ellenére az OECD jelentéseiben és dokumentumaiban az újabb oktatásgazdaságtani, emberi tőke elméleti kutatási eredmények már az 1970-es évek elején megjelentek, majd az 1970-es évek végén és az 1980-as években különösen láthatóvá váltak (pl. OECD 1989). Az 1980-as évek végén, az 1990-es évek elején azután az emberi tőke elmélet megújuló vitalitása egyre nagyobb figyelmet keltett a politikai döntéshozók körében is. Ahogy az korábban, az 1960-as években is történt, az OECD megújult érdeklődése nagyrészt a gazdasági növekedési elméletek fejlődésével függött össze. Az újabb kutatási eredmények ekkor új módszerek segítségével megerősítették az emberi tőke növekedésben játszott szerepét különösen az úgynevezett endogén növekedési 
irodalom fejlődése miatt (Romer 1986; Lucas 1988). Az új kutatási eredmények az oktatás és képzés externális hatásait is hangsúlyozták, ami még inkább lökést adott az oktatás iránti érdeklődés növekedésének. Az emberi tőke elmélet jelentőségének erősödése összefüggött azokkal a kutatási eredményekkel is, melyek a technológia szerepével és annak hatásával foglalkoztak, és melyek azt mutatták, hogy a technológia fejlődése kölcsönhatásban áll a jobb képzettségű munkavállalók iránti kereslet növekedésével (Goldin-Katz 1998).

$\mathrm{A} z$ is fontos változás volt az oktatás szerepének megítélésében, hogy a módszertanilag fejlődő oktatási megtérülési számítások már ki tudták szűrni a szelekciós torzítás hatását az oktatás megtérülési számítások eredményéből, és megerősítették, hogy az oktatás elkülöníthető hatással van az egyének munkaerőpiaci sikerességére, ami korábban komoly vita tárgya volt (Card 2001; Heckman-Lochner-Todd 2006). Az 1980-as évek végétől megfigyelhetően, az oktatás számára kedvezőbb légkörben azután az OECD számos kiadványban foglalta össze az utolsó oktatásgazdaságtani kutatások eredményeit, majd 1988-ban elindították az oktatási indikátorprojektet.

Az oktatás OECD-n belüli szervezeti elhelyezése is követte azokat a változásokat, melyek az oktatás fontosságának értékelésében bekövetkeztek az idők folyamán. Kezdetben nem volt olyan szervezeti egysége az OECD-nek, melynek feladata lett volna az oktatás tanulmányozása. 1968-ban hozták létre az Oktatási Kutatási és Innovációs Központot (Centre for Educational Research and Innovation, CERI), majd 1971-ben az Oktatási Bizottságot (Directorate for Education). A bizottságot a Tudományos Ügyek Igazgatósága (Directorate for Scientific Affair) támogatta, és először a CERI is ehhez az igazgatósághoz tartozott. 1975-ben az oktatás az új Szociális, Munkaügyi és Oktatási Igazgatóság (Directorate for Social Affairs, Manpower and Education) részévé vált. 1991-ben ezt az igazgatóságot átnevezték Oktatási, Foglalkoztatási, Munkaügyi és Szociális Igazgatóságnak (Directorate for Education Employment Labour and Social Affairs), és ez maradt az oktatás szervezeti helyszíne addig, ameddig az önálló Oktatási Igazgatóságot (Directorate for Education) 2002-ben létre nem hozták. Az önálló Oktatási Igazgatóság 2002-es létrehozásával az oktatás helyzete tovább erősödött az OECD-n belül, majd az Oktatási és Készségfejlesztési Igazgatóság (Directorate for Education and Skills) 2012-es létrehozásával még stabilabbá vált.

\section{Az oktatási indikátorrendszer története}

1973-ban az OECD kiadott egy rövid dokumentumot - „Kormányzati döntéseket segítő oktatási indikátorok keretrendszere" (A Framework for Educational Indicators to Guide Government Decisions, OECD 1973) -, melyben 46 indikátort mutattak be. Az indikátorok, az összeállítók szándéka szerint, az oktatás egyéni és társadalmi hatását kívánták mérni. Az indikátorokat az Oktatás-statisztikai és Indikátor Munkacsoport (Working Group on Educational Statistics and Indicators) jegyezte, melyet az OECD Oktatási Bizottsága hozott létre ugyancsak 1973-ban. A kiadvány hat indikátorcsoportot ismertetett, melyek a következő területeket jellemezték i) az oktatás hozzájárulása a tudásátadáshoz; ii) az oktatás hozzájárulása az egyenlő esélyekhez és társadalmi mobilitáshoz; iii) az oktatás hozzájárulása a gazdaság igényeinek kielégítéséhez; iv) az oktatás hozzájárulása az egyéni fejlődéshez; v) az oktatás hozzájárulása az értékek átadásához és fejlődéséhez; vi) az erőforrások hatékony felhasználása az előbbi célok 
érdekében. Ebben a tanulmányban az emberi tőke elmélet ma már klasszikusnak számító munkáit igen széles körűen felhasználták, így többek között Gary Becker, Jacob Mincer, T. W. Schultz, Mary Jean Bowman, Mark Blaug, Finis Welch és Zvi Griliches munkáit idézték. Olyan akadémiai kutatásokra hivatkoztak, melyek alátámasztották az oktatás gazdasági növekedéshez való hozzájárulását, vagy azt, hogy az oktatás komoly munkaerőpiaci hozamokat eredményez.

$\mathrm{A} z$ 1973-ban elindított munka az oktatási indikátorok kidolgozására azonban ekkor félbeszakadt, föleg amiatt a kedvezőtlen légkör miatt, amit az előző alfejezetben bemutattam. Az oktatás gazdasági szerepével kapcsolatos általános kételkedés volt az oka, hogy a keretrendszer kidolgozói nem tudták megszerezni a politikai döntéshozók támogatását a munkához. A döntéshozók, valamint a nemzeti kormányzatok és statisztikai hivatalaik támogatása nélkül pedig az indikátorrendszert nem lehetett kidolgozni (ld. Teixera 2019).

$\mathrm{A} z$ OECD megvalósult oktatási indikátorrendszerének kidolgozása formálisan 1988-ban kezdődött, abban az időben, amikor az érdeklődés ismét az emberi tőke elmélet felé fordult. Az Oktatási Rendszerek Nemzetközi Indikátorai (International Indicators of Education Systems, INES) projekt közvetlen előzménye két nemzetközi konferencia volt. Az elsőt Washingtonban tartották 1987-ben „Kormányközi konferencia az oktatási indikátorokról” címmel, az Egyesült Államok Oktatási Minisztériuma és az OECD közös szervezésében, ahol a részt vevő 22 ország arra a megállapításra jutott, hogy az OECD a legalkalmasabb fórum a nemzetközileg összehasonlítható oktatási indikátorok kidolgozására. Ez a konferencia elsősorban a lehetséges oktatási eredményindikátorokkal foglalkozott. A második konferenciát Franciaországban, Poitiers-ben rendezték, ahol elsősorban azzal foglalkoztak, hogy az indikátorok milyen szerepet tölthetnek be az oktatási rendszerek értékelésében. A két konferencia után az OECD Oktatási Kutatási és Innovációs Központja (CERI) igazgatótanácsa 1988 májusában jóváhagyta az indikátorprojektet.

$\mathrm{A} z$ INES program számára a fö kihívást a megfelelő statisztikai adatok hiánya és a rendelkezésre álló adatok összehasonlíthatóságának gyenge foka jelentették, ahogy Norberto Bottani, aki közel egy évtizedig vezette az INES projektet, beszámolt róla (Bottani 1994).

A nehézségek ellenére 1991-ben a projekt munkatársai bemutatták az Education at a Glance első kiadásának tervezetét, melyben harminc indikátorra vonatkozóan gyüjtötték össze az adatokat, melyek között voltak viszonylag hagyományos mutatók, mint például a részvételi arányok, és új, összetettebb mutatók is, melyek például az oktatási rendszerek döntéshozatali jellemzőit mutatták be. A találkozón különösen a kevésbé hagyományos mutatók ismertetése nagy vitát váltott ki, elsősorban az, hogy a kiadvány az IEA (International Association for the Evaluation of Educational Achievement - Nemzetközi Szövetség az oktatási eredmények értékelésére) tanulói teljesítménymérésének (TIMMS) adatait is felhasználta az oktatási rendszer eredményességének mérésére. $\mathrm{E} z$ a találkozó indított el két további kiadványt az „OECD nemzetközi oktatási indikátorai: elemzési keret” és a "Számítson az oktatás” (Making Education Count, OECD 1994) címü munkákat is, melyek az indikátorokkal kapcsolatos számos módszertani kérdéssel foglalkoztak, és bemutatták, hogy mely kérdéseket nem sikerült akkor még megoldani. 
Az első Education at a Glance (EAG) kötet 1992-ben jelent meg, a következő kötetek 1993-ban és 1995-ben, majd azóta minden év szeptemberében megjelent az EAG. Az EAG adatait ma már rutinszerűen használják az oktatáspolitikával vagy oktatáskutatással foglalkozók.

A z első oktatási indikátorkötet megjelenését követő három évtizedben az INES program müködése egyre formalizáltabbá vált. Az INES programot három szerv felügyeli és koordinálja: az OECD Oktatáspolitikai Bizottsága a program stratégiai irányát, a koherenciát és a minőséget felügyeli, az INES tanácsadó csoport, amely koordinálja az INES-hez kapcsolódó munkát és az INES munkacsoport, amely a jelentések prioritásait határozza meg és felügyeli az adatfejlesztést. Amikor az oktatás 2002-ben külön igazgatóság irányítása alá került az OECD-n belül, akkor létrehoztak egy, az oktatási indikátorokért felelős elemzési részleget, amely jelenleg az INES-t és az OECD egyéb, oktatással kapcsolatos adatfelvételeit is kezeli. Ez azt mutatta, hogy az oktatási indikátorok készítését az OECD már a szervezet alaptevékenységének tekinti.

Az elmúlt évtizedekben egyre bővült a részt vevő országok köre, az OECD tagországain kívül egyre több tagjelölt és partnerország is részt vesz az adatszolgáltatásban. Az 1992-es kiadvány 26 országra vonatkozóan közölt adatokat, a 2020-ban megjelent kötet már 46 országra vonatkozóan.

\section{$\mathrm{Az}$ OECD oktatási indikátorrendszerének változásai}

$\mathrm{Az}$ indikátorkötetekben szereplő indikátorok többféle, egyre bővülő adatforráson alapulnak. Mivel egyre több adatforrás állt rendelkezésre, ezek felhasználásával folyamatosan fejleszteni lehetett a mutatószámokat.

A $z$ adatforrások között szerepel a kezdetek óta az UNESCO, OECD és EUROSTAT (UOE) közös adatfelvétele, mely az oktatási részvételi arányokról, az oktatásba újonnan belépőkről, a végzettekről, az oktatásban dolgozókról, az osztálylétszámokról, az oktatás finanszírozásáról és más kérdésekről gyüjt statisztikai adatokat. Ezek aggregált adatok, melyek összehasonlíthatóságának biztosítására az OECD komoly munkát végzett. A legutolsó években három új kézikönyvet adtak ki abból a célból, hogy elősegítsék az oktatásstatisztikai adatgyüjtés nemzetközi összehasonlíthatóságát (OECD 2004, 2017, 2018), melyek részletesen ismertetik az EAG kötetekben szereplő indikátorok számításának módszereit.

$\mathrm{A} z$ OECD oktatási indikátorrendszerének fejlesztésében nagyon fontos fejlemény volt, hogy az OECD saját, nemzetközi adatfelvételeket kezdett végezni, melyek adatait azután - többek között - az indikátorok továbbfejlesztésében is használták/használják. Ezek az adatfelvételek olyan kérdéseket vizsgálnak, melyek az oktatásgazdaságtani kutatások szerint az oktatás eredményességének meghatározóit vagy magukat az oktatás összehasonlítható eredményeit mérik. Az utóbbira példa az OECD első és legismertebb oktatási adatfelvétele, a 15 éves tanulók teljesítményét felmérő PISA (Programme for International Student Assessment) vizsgálatok. Az első PISA adatfelvétel 2000-ben volt, azóta három évente ismétlődnek.

A PISA adatfelvételek alapján számított indikátorokat 2002 óta közölnek az EAG kötetetek. Az OECD egy másik, az indikátorkötetekben is használt adatfelvétele a TALIS adatfelvételek (Teaching and Learning International Survey), melyek a tanítás és 
tanulás feltételeit mérik fel, elsősorban a tanárok munkakörülményeit. Az első TALIS adatfelvétel 2008-ban volt. Az OECD a felnőtt kompetenciák nemzetközi felmérésére vonatkozó programja (Programme for the International Assessment of Adult Competencies, PIAAC) 2012-ben indult, mely a felnőttek készségeit és kompetenciáit méri fel, valamint hogy ezeket hogyan használják a munkahelyen, otthoni vagy más környezetben. Ezekre az adatokra alapozva is újabb indikátorokkal tudják vizsgálni az oktatás eredményességét.

$\mathrm{Az}$ OECD saját adatfelvételei nemcsak az indikátorprojektben használhatóak, hanem az adatfelvételek eredményeként olyan összehasonlítható, mikroszintü adatbázisok jöttek létre, melyek kutatási célokra is nagyon jól használhatók, az adatbázisok ökonometriai módszerekkel jól vizsgálhatók. Az OECD igyekszik ösztönözni ezeket a kutatásokat, melyek eredményeit aztán felhasználják többek között a további indikátorfejlesztő munkájukban.

A indikátorkötetekhez a rendszeres adatfelvételek mellett időről időre ad hoc felméréseket is végeznek, hogy egyéb információkat gyűjtsenek, például a közép- és felsőfokú végzettségi arányokat, a hallgatói mobilitásra vonatkozó adatokat és a diákhiteladatokat.

A mutatók keretrendszere az elmúlt évtizedekben egy nagyobb átalakításon esett át 2002-ben. A kezdeti időszakban, 1992 és 2001 között többször változtattak az indikátorcsoportok összeállításán. Az 1992-es kiadványban az oktatási indikátorokat hat csoportra bontották: 1 . az oktatás kontextusát leíró; 2. a költségeket, forrásokat és iskolai folyamatokat bemutató; 3 . az oktatási részvételt, előrehaladást jellemző; 4. az oktatási döntéshozatalt ismertető; 5. a tanulási eredményeket; és 6. az oktatási rendszer egészének végzettségben, munkaerőpiaci sikerességben mérhető eredményeit bemutató csoportokra. A következő kiadásokban azután volt, hogy az iskolából a munkába átmenetet leíró mutatószámoknak önálló csoportot képeztek, vagy hogy egyéb változtatásokat végeztek a csoportokban.

2002-ben teljesen átstrukturálták az indikátorok csoportjait, azóta négy csoportot különböztetnek meg az EAG kiadványok. Az új csoportok a következők: 1. Az oktatási intézmények outputja és a tanulás hatása; 2 . az oktatásba befektetett pénzügyi és humán erőforrások; 3. hozzáférés, részvétel, továbbhaladás; és 4. tanulási környezet, az iskolák szervezete. Az utóbbi csoport 2018 óta a „Tanárok, tanulási környezet és az iskolák szervezete" nevet viseli, miután egyre több, a tanárokat jellemző indikátort tartalmaz.

Az egyes indikátorcsoportokban cserélődik a mutatószámok egy része, újabb és újabb indikátorokat vonnak be a kiadványokba, míg másokat elhagynak, hogy a kiadványok kezelhető mennyiségü indikátort tartalmazzanak csak. Bár sok korábbi mutatót már nem közölnek a kiadványokban, de online ezek az adatok is hozzáférhetőek maradnak, és frissítik is őket újabb adatokkal. Az egyes indikátorcsoportokba bevont új indikátorok legtöbbször követik az oktatásgazdaságtani, oktatási kutatások újabb eredményeit. A 2001-es kiadványban például a humán tőke gazdasági növekedéshez történő hozzájárulását jellemző mutatószámot közöltek, 2002 óta közölnek az oktatás megtérülési rátáira vonatkozó indikátorokat. 2009 óta lettek hangsúlyosak a kötetekben a tanárok jellemzőit bemutató indikátorok, azoknak a tanulmányoknak a publikálása után, melyek oksági elemzésekkel mutatták ki a tanárok meghatározó hatását a tanulói teljesítményekre (pl. Rockoff 2004; Bonesrønning-Falch-Strøm 2005; Rivkin-Hanushek-Kain 2005). A kiadványok egyre inkább igyekeznek azokat a tényezőket is megragadni in- 
dikátorok segítségével, melyekről az újabb kutatások azt találták, hogy befolyásolják a tanulói eredményességet. 2013 óta közölnek például a kora gyerekkori nevelésre vonatkozó indikátorokat (a kora gyerekkori nevelés későbbi hatásáról lásd pl. Belfield et al. 2006; Heckman 2011). 2020-ban új, hangsúlyos témaként jelent meg a szakképzés az EAG kiadványban. Az indikátorkötetekbe újonnan bekerülő témák egy-két évvel korábban általában nagyon hangsúlyosak az oktatásgazdaságtani irodalomban.

$\mathrm{A} z$ OECD jól megtervezett, ismétlődő adatfelvételeivel ugyanakkor a kutatással való kapcsolat kölcsönössé vált. Az OECD már nemcsak felhasználja a kutatási eredményeket az indikátorfejlesztő munkában, hanem ösztönzést is ad a további kutatásoknak. A nemzetközileg összehasonlítható mikroszintű adatbázisok lehetőséget adnak korábban adatok hiányában nem vizsgálható kérdések empirikus vizsgálatára, oksági hatások feltárására, így például a különböző oktatáspolitikai eszközök hatásának megítélésére.

\section{A $z$ indikátorok disszeminációja}

$\mathrm{A} z$ EAG kötetek megjelentetése mellett az OECD igyekszik az indikátorprogram eredményét minél célozottabban eljuttatni a különböző potenciális felhasználókhoz: a politikai döntéshozók, oktatók, kutatók és a nyilvánosság tagjai számára eltérő kiadványok formájában terjesztik az eredményeket.

A „Fókuszban az oktatási indikátorok” (Education Indicators in Focus) kiadvány egy-egy érdeklődésre számot tartható indikátort emel ki az EAG kötetekből és diagramok, rövid tájékoztatók segítségével nyújt tájékoztatást egy adott kérdésről. Az „EAG országspecifikus megjegyzések” (Education at a Glance Country Notes) kiadványai minden, a kötetben szereplö ország legfontosabb adatait külön-külön ismerteti rövid, könnyen olvasható formában, sok diagram segítségével. A kiadvány bemutatja az adott ország oktatási rendszeréről a legfontosabb megállapításokat, és kiemeli, hogy az adott ország melyik területeken sikeres vagy küzd kihívásokkal. A kiadvány ismerteti az adott ország oktatáspolitikai fejleményeit is. Az „EAG föbb jellemzők” (Education at a Glance Highlights) szintén évente megjelenő kiadvány kivonatokat közöl az EAG adataiból, bemutatja a tanulói létszámra, az oktatás gazdasági és társadalmi előnyeire, az oktatásfinanszírozásra és az iskolai környezetre vonatkozó legfontosabb diagramokat és táblázatokat. Az „EAG navigátor” (Education at a Glance Navigator) politikai döntéshozók, kutatók és szakemberek számára készült online eszköz, amely lehetővé teszi, hogy a felhasználók konkrét mutatókat keressenek és összehasonlítsák a különböző országok eredményeit online diagramokon és táblázatokon keresztül. Végül az „OECD.stat” online felületen ingyenesen letölthetők azok a nyers adatok, amelyeket az országok nyújtanak be az EAG és más OECD-kiadványokban bemutatott mutatók összeállításához. Ahogy korábban már szó volt róla az OECD saját adatfelvételeinek (PISA, TALIS, PIAAC) egyéni szintű, kutatói adatbázisai - a kérdőívekkel, technikai útmutatókkal és egyéb magyarázó anyagokkal együtt - ugyancsak ingyenesen letölthetők az adatfelvételek honlapjáról.

Az EAG kötetek első megjelenésük óta nagyon sokat fejlődtek összehasonlíthatóságban, megbízhatóságban. Az indikátorrendszer kialakításával vette kezdetét az OECDben az a munka, mely a szervezeten belül az oktatás felértékelődéséhez vezetett, és 
melynek nyomán az OECD-ben létrejött az összehasonlítható statisztikai adatbázisokból és a mikroszintű adatbázisokból egy olyan egyedülálló, nemzetközi adatbázis, mely komoly alapot jelent az oktatásgazdaságtani, oktatáspolitikai kutatásokhoz. Ezzel egyidejüleg az OECD-n belül is létrejött az oktatási indikátorokhoz, oktatási adatfelvételekhez kapcsolódó szakértelem, ami megkerülhetetlenné teszi, hogy az oktatással foglalkozó kutatók, oktatáspolitikusok és más szakemberek az OECD adatait, indikátorait, indikátorköteteit és egyéb kiadványait is használják munkájukhoz.

\section{IRODALOM}

Arrow, K. (1973) Higher Education as a Filter. Journal of Public Economics, Vol. 2. No. 3. pp. 193-216.

Becker, G. (1962) Investment in Human Capital: A Theoretical Analysis. Journal of Political Economy, Vol. 70. No. 5. Part 2. pp. 9-49. http://dx.doi.org/10.1086/258724

Belfield, C. R., Nores, M., Barnett, S. \& Schweinhart, L. (2006) The High/Scope Perry Preschool Program Cost-Benefit Analysis Using Data from the Age-40 Follow Up. Journal of Human Resources, Vol. 41. No. 1. pp. 162-190.

Berg, I. (1970) Education and the Jobs: The Great Training Robbery. New York, Praeger.

Bonesrønning, H., Falch, T. \& Strøm, B. (2005) Teacher Sorting, Teacher Quality, and Student Composition. European Economic Review, Vol. 49. No. 2. pp. 457-483.

BotтAni, N. (1994) The OECD International Education Indicators. Assessment in Education: Principles. Policy and Practice, Vol. 1. No. 3. pp. 333-350.

Bürgi, R. (2017) Engineering the Free World: The Emergence of the OECD as an Actor in Education Policy, 1957-1972. In: M. Leimgruber \& M. Schmelzer (eds) The OECD and the International Political Economy Since 1948. Cham, Palgrave Macmillan. pp. 285-309.

Card, D. (2001) Estimating the Returns to Schooling: Progress on Some Persistent Econometric Problems. Econometrica, Vol. 69. No. 5. pp. 1127-1160. DOI: 10.1111/14680262.00237

Denison, E. F. (1962) The Sources of Economic Growth in the United States and the Alternatives before Us (“Supplementary Paper No. 13") [New York: Committee for Economic Development, 1962

Denison, E. F. (1967) Az oktatás, a gazdasági növekedés és a hiányos információ. In: A gazdasági növekedés feltételei. Budapest, Közgazdasági és Jogi Könyvkiadó.

Denison, E. F. (1974) Accounting for United States Economic Growth, 1929-1969. Washington (D.C.), Brookings Institution.

Denison, E. F. (1985) Trends in American Economic Growth, 1929-1982. Washington (D.C.), Brookings Institution.

Goldin, C. \& Katz, L. F. (1998) The Origins of Technology-Skill Complementarity. The Quarterly Journal of Economics, Vol. 113. No. 3. pp. 693-732.

Grek, S. (2009) Governing By Numbers: The PISA 'Effect' in Europe. Journal of Education Policy, Vol. 24. No. 1. pp. 23-37.

Heckman, J. J. (2011) The Economics of Inequality: The Value of Early Childhood Education. American Educator, Vol. 35. No. 1. pp. 31-47.

Heckman, J. J., Lochner, L. J. \& Todd, E. (2006) Earnings Functions, Rates of Return and Treatment Effects: The Mincer Equation and Beyond. In: E. A. Hanushex \& F. Welch (eds) Handbook of the Economics of Education. Amsterdam, Elsevier. Vol. 1. Chap. 7. pp. 307-458. 
Lucas, R. (1988) On the Mechanics of Economic Development. Journal of Monetary Economics, Vol. 22. No. 1. pp. 3-42. DOI: 10.1016/0304-3932(88)90168-7

OECD (1960) Convention on the Organisation for Economic Co-operation and Development. Paris, OECD.

OECD (1962) Planning Education for Economic and Social Development. Paris, OECD Publishing.

OECD (1973) Indicators of Performance of Educational System. Paris, OECD.

OECD (1989) Education and the Economy in a Changing Society. Paris, OECD.

OECD (1992) OECD International education indicators: a framework for analysis. Paris, OECD.

OECD (1994) Making Education Count. CERI. Paris, OECD.

OECD (2004) OECD Handbook for Internationally Comparative Education Statistic. Concepts, Standards, Definitions and Classifications. Paris, OECD.

OECD (2017) OECD Handbook for Internationally Comparative Education Statistics: Concepts, Standards, Definitions and Classifications. Paris, OECD Publishing. http://dx.doi. org/10.1787/9789264279889-en

OECD (2018) OECD Handbook for Internationally Comparative Education Statistics 2018: Concepts, Standards, Definitions and Classifications. Paris, OECD Publishing. https://doi. org/10.1787/9789264304444-en

Papadopoulos, G. (1994) Education 1960-1990. The OECD Perspective. Paris, OECD.

Rivinin, S. G., Hanushex E. A. \& Kain J. F. (2005) Teachers, Schools and Academic Achievement. Econometrica, Vol. 73. No. 2. pp. 417-458.

Rockoff, J. E. (2004) The Impact of Individual Teachers on Student Achievement: Evidence from Panel Data. American Economic Review, Vol. 94. No. 2. pp. 247-252.

Romer, P. (1986) Increasing Returns and Long-Run Growth. Journal of Political Economy, Vol. 94. No. 5. pp. 1002-1037. DOI: 10.1086/261420

Schultz, T. W. (1961a) Education and Economic Growth. In: N. B. Henry (ed.) Social Forces Influencing American Education. Chicago, University of Chicago Press.

Schultz, T. W. (1961b) Investment in Human Capital. American Economic Review, Vol. 51. Nos 1-17. Magyarul: T. W. Schultz: Beruházás az emberi tőkébe. Közgazdasági és Jogi Könyvkiadó, Budapest, 1983.

Solow, R. (1967) A technikai változás és az aggregált termelési függvény. In: Sza kolczaI Gy. (ed.) A gazdasági növekedés feltételei. Közgazdasági és Jogi Könyvkiadó, Budapest.

Spence, M. (1973) Job Market Signalling. The Quarterly Journal of Economics, Vol. 87. No. 3.pp. 355-374.

Teixeira, P. N. (2019) Early Interest, Lasting Scepticism: The Views about Education at the OECD (1960s-1980s). conomia. History, Methodology, Philosophy, Vol. 9. No. 3. pp. 559-581.

Tinbergen, J. \& Bos, H. C. (1964) A Planning Model of Educational Requirements of Economic Development. In: OECD/Study Group in the Economics of Education. The Residual Factor and Economic Growth. Paris, OECD. pp. 147-170.

A cikk a Creative Commons Attribution 4.0 International License (https://creativecommons.org/licenses/bync/4.0/) feltételei szerint publikált Open Access közlemény, melynek szellemében a cikk bármilyen médiumban szabadon felhasználható, megosztható és újraközölhető, feltéve, hogy az eredeti szerző és a közlés helye, illetve a CC License linkje és az esetlegesen végrehajtott módosítások feltüntetésre kerülnek. 